\title{
EFFECTS OF COAXIAL DIELECTRIC BARRIER DISCHARGE ON WATER TREATMENT AT DIFFERENT SITES OF KATHMANDU VALLEY, NEPAL
}

\author{
H. P. Gyawali ${ }^{1}$,J. Shrestha ${ }^{2}$, N. Nakarmi ${ }^{2}$, R. B. Tyata $^{3}$ \\ ${ }^{l}$ Khwopa Engineering College, Libali-8, Bhaktapur, Nepal \\ ${ }^{2}$ St. Xavier's College, Maitighar, Kathmandu, Nepal \\ ${ }^{3}$ Khwopa College of Engineering, Libali-8, Bhaktapur, Nepal
}

\begin{abstract}
The research work reports the results concerning the effects of ozone produced by dielectric barrier discharge (DBD) in well, river and industrial wastewater. The dielectric barrier discharge (DBD) unit was developed to produce highly oxidizing ozone molecules, hydrogen peroxide and hydroxyl radicals for the treatment of water. The discharge was produced by applying AC high voltage (up to $10 \mathrm{kV}$ peak-to-peaks) source of frequency 26 $\mathrm{kHz}$ across annular electrodes. The well and wastewater samples were collected from 5 different places of Kathmandu district, Nepal. Various physical, chemical and micro-biological parameters such as $\mathrm{pH}$, Electrical Conductivity (EC), Dissolved Oxygen (DO), Biological Oxygen Demand (BOD), Chemical Oxygen Demand (COD) and Total Coliform were analysed before and after ozonation. Our results showed that $\mathrm{pH}$ of water after treatment changed slightly with respect to $\mathrm{pH}$ of untreated water. There was slight change in conductivity of water from the different sources after treatment by ozone. DO of all samples increased significantly after ozonation. It was found that BOD and COD of all samples decreased significantly after ozonation. Concentration of ferrous ion $\left(\mathrm{Fe}^{2+}\right)$ decreased after ozonation. There was significant decrease in Total Coliform after treatment.
\end{abstract}

Keywords: Dielectric barrier discharge (DBD), Ozonation, well water, wastewater.

\section{Introduction}

Wastewater consists of large numbers of biological pollutants, living micro-organisms, bacteria, protozoa, fungi and many other contaminants (Mohamed E. et al., 2013). Water becomes polluted due to various human activities such as direct release of solid and liquid waste of industries and domestic sewage wastewater into rivers and lakes; excessive use of chemical fertilizers, pesticides and insecticides pollutes water while it rains. This causes increase in water crisis and environmental deterioration (Bhatta R. et al., 2015).

\footnotetext{
*Corresponding author: Hari Prasad Gyawali Khwopa Engineering College, Libali-8, Bhaktapur Email: hp_gyawali@yahoo.com

(Received: Dec 05, 2017 Accepted: May 01, 2018)
}

The increasing pace of urbanization and population growth continues to affect the quality of drinking water. The increasing consumption of water and discharge of wastewater has been resulted with the growing population and rising economy, which causes huge pollution (Omosa I. B. et al., 2012). Water pollution causes reduction in available freshwater, and affects human health and ecosystem also (Armstrong A. 2009; Pickering A.J. et al., 2012; Montgomery M. A. et al., 2007). Therefore, wastewater treatment is one of the crucial issues in many cities around the world.

There are various methods for the treatment of wastewater. Conventional wastewater purification methods include decontamination agents like chlorine, chlorine dioxide or by using ultraviolet radiation and hydrogen peroxide (Droste R. 1996). 
Chemical treatment processes for the purification of wastewater are expensive, and the final products might be as toxic as primary substances. On the other hand, biological treatment is effective to remove a wide range of pollutants, but it may change temperature, $\mathrm{pH}$ values and the characters of the pollutants. According to latest studies, one of the emerging technologies for wastewater treatment is advanced oxidation processes (AOPs) (Glaze W. H. et al., 1987). The COD and BOD levels are reduced, and both organic and oxidizable inorganic components are removed by the use of oxidants produced from advanced oxidation processes. AOPs can completely oxidize organic materials to carbon dioxide and water. For water purification using AOPs, ozone produced by dielectric barrier discharge (DBD) has been proved effective. The area of water purification by ozone synthesis is an industrially accepted application of electric discharges (Bubnov A. G. et al., 2004; Chang M. B. and Wu S. J. 1997; Eliasson B. et al., 1987). In plasma technology such as DBD; ions, high-reactive short-lived oxygen and nitrogen radicals, ozone, $\mathrm{H}^{+}$, etc are generated from air or atmospheric oxygen. These reactive particles which are generated during discharge react rapidly with dissolved pollutants in water due to their high reactivity and reduce the contaminants in water. Therefore, AOPs are commonly used techniques for water purification (Quyen N. T. et al., 2017). DBD cold plasma is alternative to conventional disinfectant methods in water treatment due to its efficient antibacterial activity at a short period of time (Razuqi N.S. et al., 2017).

The dissociation of oxygen molecules takes place when air is passed through the DBD under the influence of high energy electrons within the inter electrode space. The atomic oxygen combines with another oxygen molecule to form ozone. When ozone is passed through water the chemical or biological properties of water may change.

$\mathrm{O}_{2} \rightarrow \mathrm{O}^{*}+\mathrm{O}^{*} \quad \mathrm{O}^{*}+\mathrm{O}_{2} \rightarrow \mathrm{O}_{3}$

Ozone, thus produced, is released into the water where it oxidizes various organic and inorganic chemicals present in water and converts them into simpler form which gets easily decomposed in the nature (Malik M. A. et al., 2001).

\section{Experimental Set up of DBD}

The experimental setup used for ozone generation in this study is shown in Fig.1. The discharge from dielectric barrier was generated using high voltage (up to $10 \mathrm{kV}$ peak-to-peaks) AC power supply operating at $26 \mathrm{kHz}$ across annular electrodes. The electrode system used was coaxial cylindrical. The anode was connected to the central copper rod placed inside the glass tube, and cathode was connected to an aluminum sheet wrapped around a glass tube. The thickness of glass was $1.8 \mathrm{~mm}$. The gas was passed inside the tube through the gap between the anode and the glass tube of $1.85 \mathrm{~mm}$ thickness. The concentration of ozone dissolved in water was determined by using the iodometric titration method. The concentration of ozone passed was $1.2 \mathrm{mg} / \mathrm{l}$ for 2 minutes treatment and $2.4 \mathrm{mg} / \mathrm{l}$ for 3 minutes treatment. The specification of the DBD system is given below. Diameter of copper rod is $3.18 \mathrm{~mm}$, and length of outer electrode and central electrode are $4.73 \mathrm{~cm}$ and $12.54 \mathrm{~cm}$ respectively. The thickness of dielectric (glass) is $1.8 \mathrm{~mm}$, whereas internal diameter of glass used is $8.05 \mathrm{~mm}$, and thickness of aluminum sheet is $0.14 \mathrm{~mm}$. The experimental setup used for ozone generation from DBD was established in the physics laboratory of Khwopa Engineering College, Bhaktapur. The concentration of ozone dissolved in water was determined in the chemistry laboratory of Khwopa Engineering College, Bhaktapur. The chemical and microbiological analyses of the water samples were done in the chemistry and microbiology laboratory of St. Xavier's College, Kathmandu.

Samples were collected from five different places of Kathmandu district, namely well water in Manamaiju $\left(\mathrm{S}_{1}\right)$, waste water of microbiology laboratory of St. Xavier's College $\left(\mathrm{S}_{2}\right)$, waste water of Bagmati river near Pashupatinath temple $\left(S_{3}\right)$, waste water of dairy factory $\left(\mathrm{S}_{4}\right)$ and waste water of coke factory $\left(\mathrm{S}_{5}\right)$ in Balaju. Physicochemical and microbiological parameters to be tested and test methods are shown in table 1 . Standard test methods were followed for analysis. Data analysis was done by calculating the correlation coefficients between different samples for different parameters to check if the values were consistent or not. 


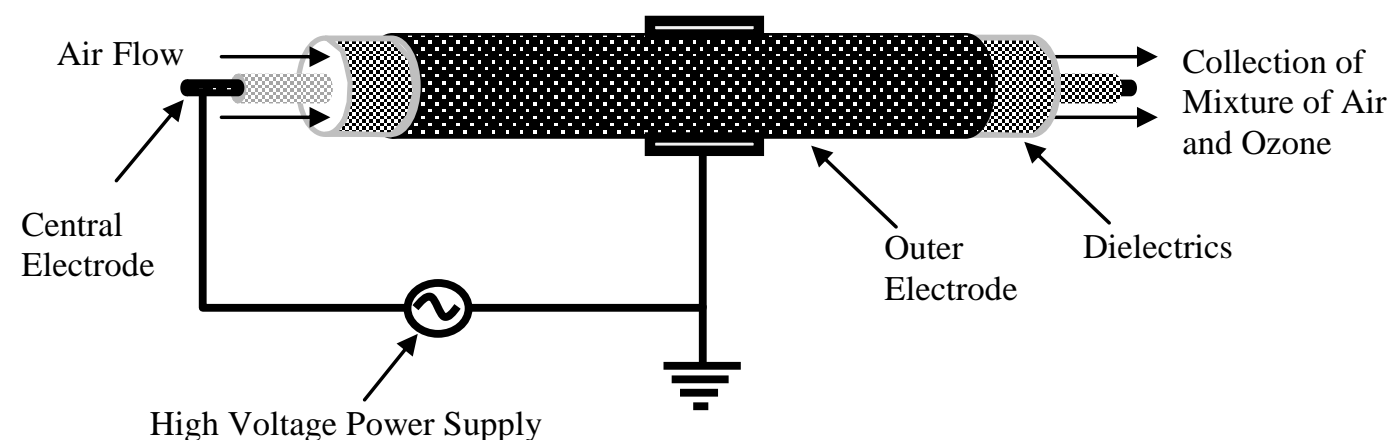

Fig. 1 Experimental set up of DBD system for ozone generation

Table1: Parameters to be tested and test methods

\begin{tabular}{|c|c|l|}
\hline Parameters & Units & Test methods/ Instruments \\
\hline $\mathrm{pH}$ & - & $\mathrm{pH}$ meter (model SI-139, DICA India) \\
\hline Conductivity & $\mu \mathrm{s} / \mathrm{cm}$ & Conductivity meter (HI 8033, HANNA instruments) \\
\hline $\mathrm{DO}$ & $\mathrm{mg} / \mathrm{ml}$ & Winkler's iodometric method (Azide modification method) \\
\hline $\mathrm{BOD}$ & $\mathrm{mg} / \mathrm{l}$ & Winkler's iodometric method (Azide modification method) \\
\hline $\mathrm{COD}$ & $\mathrm{mg} / \mathrm{l}$ & Open reflux method \\
\hline Ferrous ion & $\mathrm{mg} / \mathrm{l}$ & $\begin{array}{l}\text { Phenanthroline method and use of colorimeter (CE 51457 Invitro Biotech. } \\
\text { Ltd.) }\end{array}$ \\
\hline $\begin{array}{c}\text { Total } \\
\text { coliform }\end{array}$ & MPN/100ml & Most probable number(MPN) procedure on Macconkey Broth \\
\hline
\end{tabular}

\section{Result and Discussion}

\section{1. pH Analysis}

Fig. 2 shows the $\mathrm{pH}$ analyses of untreated and treated water samples from five different sources. $\mathrm{pH}$ of untreated water samples from $\mathrm{S}_{1}$ to $\mathrm{S}_{5}$ were 6.6,7.3,7.8,10.7 and 6.6 respectively. For sample $\mathrm{S}_{2}, \mathrm{pH}$ was found to be 7.4 after 2 and 3 minute treatment while for $\mathrm{S}_{3}$, $\mathrm{pH}$ didn't change even after treatment. For other samples $\mathrm{S}_{1}, \mathrm{~S}_{4}$ and $\mathrm{S}_{5}, \mathrm{pH}$ were found to be 7.0,10.8 and 7.1 after 2 minutes treatment, and 7.3,10.9 and 7.6 after 3 minutes treatment showing a slight increase in $\mathrm{pH}$ after treatment. $\mathrm{pH}$ of water sample $\mathrm{S}_{1}$ is found to be much close to the neutral value of 7 as compared to other samples .In the case of water sample $\mathrm{S}_{3}$, there is no change in $\mathrm{pH}$ before and after treatment. It was also observed that $\mathrm{pH}$ of treated water samples are within the WHO acceptable concentration range 6.5 to 8.5 (World Health Organization, 2007) for drinking, except in water sample $\mathrm{S}_{4}$.

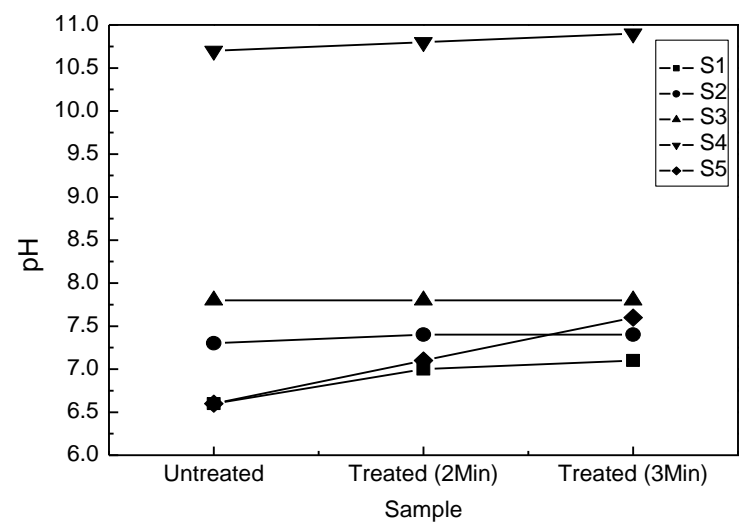

Fig. $2 \mathrm{pH}$ of samples

The increase in $\mathrm{pH}$ of water after treatment may be due to the accumulation of $\mathrm{H}_{2} \mathrm{O}_{2}$ during the treatment (Subedi D.P. et al., 2012). The correlation coefficients between each pair of samples except $\mathrm{S}_{2}$ were at least 0.86 to 0.98 . It shows that $\mathrm{pH}$ is increased in four samples in almost same pattern. 


\subsection{Conductivity Analysis ( $\mu \mathrm{S} / \mathrm{cm})$}

The conductivity analyses of untreated and treated water samples are depicted in Fig.3.The conductivity of untreated water samples lies in between $600 \mu \mathrm{S} / \mathrm{cm}$ to $1120 \mu \mathrm{S} / \mathrm{cm}$. The conductivity of water samples, which were treated for 2 minutes, lies in between $580 \mu \mathrm{S} / \mathrm{cm}$ to $1060 \mu \mathrm{S} / \mathrm{cm}$ and those water samples, treated for 3 minutes lies in between $480 \mu \mathrm{S} / \mathrm{cm}$ to $1040 \mu \mathrm{S} / \mathrm{cm}$. The conductivity of four samples decreased slightly after treatment and that of one sample didn't change even after treatment. It was also observed that there was no significant change in conductivity of water samples before and after treatment. Conductivity is directly related to the amount of salts dissolved in water, and ozonation does not contribute to addition of extra ions. It was observed that correlation coefficients between each pair of samples except $\mathrm{S}_{4}$ were at least 0.62 to 0.97 . It shows that the conductivity decreased in four samples in fairly same pattern.

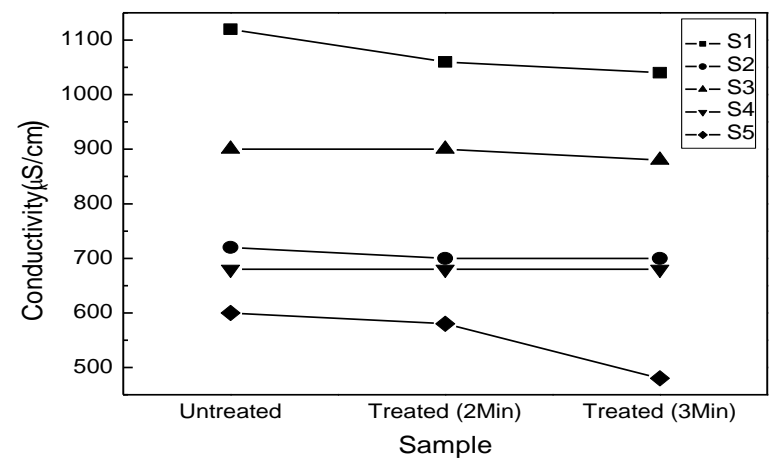

Fig. 3 Conductivity of samples

\subsection{Dissolved Oxygen (DO) Analysis (mg/L)}

Fig. 4 shows DO of untreated and treated water samples. DO of the untreated water samples from $\mathrm{S}_{1}$ to $\mathrm{S}_{5}$ were 5.2, 6.0, 3.2, 6.4 and 6.1 respectively before treatment. After treatment with ozone for 2 minutes, DO values of water samples were found to be 5.6, 7.2, 4.0, 6.8 and 6.8 and after treatment for 3 minutes, the values were 6.4, 7.6, 4.4, 7.1 and 7.0 respectively. From the above data, it is clear that DO of all samples increased significantly after treatment with ozone. DO levels depend on the water and atmosphere interface, production through photosynthesis, consumption by plants, animals and decomposer organism in respiration. Minimum DO level required for protection of aquatic life is 5.8mg/l to $6.8 \mathrm{mg} / \mathrm{l}$ (Goel P. K. 2006). It was observed that correlation coefficients between samples $S_{1}$ and $S_{5}$ was 0.88 which is minimum and that of $S_{2}$ and $S_{3}$ was 1.00 which is maximum. It shows that DO increased in each sample in a consistent way.

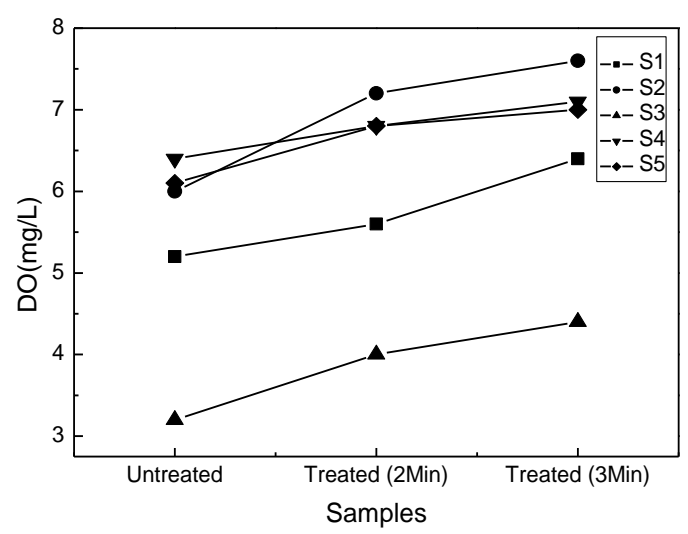

Fig. 4 DO of samples

\subsection{Biological Oxygen Demand (BOD) Analysis (mg/L)}

BOD is defined as the amount of oxygen required by the microorganism in stabilizing the biologically degradable organic matter under aerobic conditions. Fig. 5 shows BOD of untreated and treated water samples from different sources. BOD of sample $S_{1}$ was 16 before treatment, and it was reduced to 8 and 4 after treatment for 2 and 3 minutes respectively.

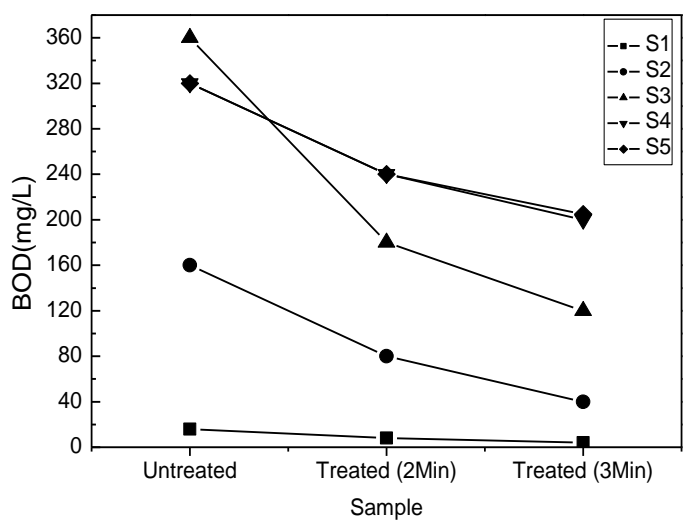

Fig. 5 BOD of samples

Similarly, for other samples $\mathrm{S}_{2}, \mathrm{~S}_{3}, \mathrm{~S}_{4}$ and $\mathrm{S}_{5}, \mathrm{BOD}$ was reduced from 160 to 80 and 40, 360 to 180 and 120,320 to 240 and 200, 320 to 240 and 205 respectively after treatment by ozone for 2 and 3 minutes showing significant decrease in BOD after treatment. In all the samples BOD decreased 
significantly after ozonation. The correlation coefficient between each pair of samples is at least 0.99 showing decrease in BOD in a consistent way.

\subsection{Chemical Oxygen Demand (COD) Analysis $(\mathrm{mg} / \mathrm{L})$}

Fig. 6 shows COD of untreated and treated water samples from different sources. COD of untreated water samples were found between195.2 to 641.6. After treatment by ozone for 2 minutes, COD of water samples ranged between 156.8 to 491.2 and after 3 minutes treatment it was ranged between 137.6 to 278.4 showing significant decrease in COD after treatment. In all the samples COD decreased significantly after ozonation. Decrease in COD may be due to the presence of series of chain reactions initiated by ozone which fragmentize large organic molecules in water (Subedi D. P. et al., 2009). The correlation coefficient between each pair of samples is at least 0.93 to 1.00 . It shows that COD decreased in each samples in a consistent way.

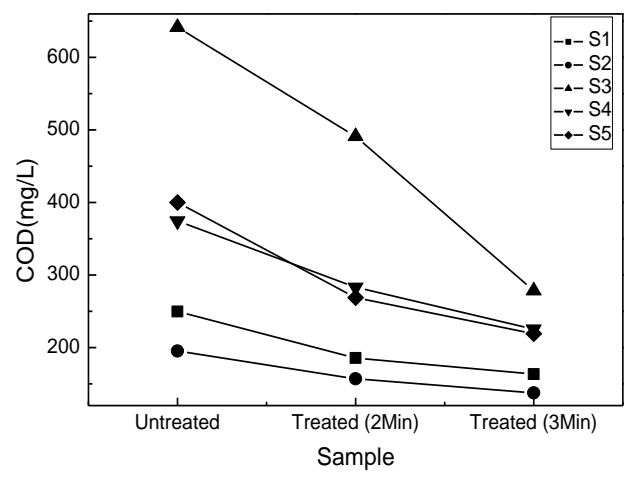

Fig. 6 COD of samples

\subsection{Ferrous Ion Concentration Analysis $(\mathrm{mg} / \mathrm{L})$}

Fig. 7 shows ferrous ion concentration analyses of untreated and treated water samples. In all water samples concentration of ferrous ion decreased after treatment. Concentration of ferrous ion of water samples lies between 10.7 to 21.5 before treatment. After 2 minutes treatment by ozone the range reduced to10.6 to 18 and after 3 minutes treatment the range was10.6 to 17.1. After treatment the $\mathrm{Fe}^{2+}$ concentration was found to decrease slightly in sample $S_{1}$ while for other samples it was reduced significantly. Iron in its ferrous state has charge of $2+$. When ozone is passed through the solution containing ferrous salts, it contributes the oxygen atom that reacts with the $\mathrm{Fe}^{2+}$ to give ferric salt and hence concentration of $\mathrm{Fe}^{2+}$ decreases (Subedi D. P. et al., 2012). The correlation coefficient between each pair of samples is at least 0.91 to 0.99 showing decrease in ferrous ion in almost same pattern.

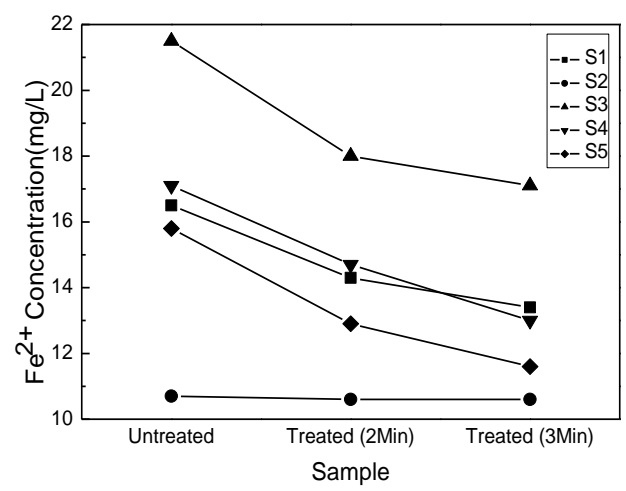

Fig. $7 \mathrm{Fe}^{2+}$ concentration of samples

\subsection{Total Coliform Analysis (MPN/100ml)}

Fig. 8 shows total coliform analyses of untreated and treated water samples. Total coliform decreased significantly in all the samples after treatment. Maximum total coliform count of different samples were 23, 47, 93 and above 1100 before treatment. After treatment for 2 minutes, the total coliform reduced to nil in sample $S_{4}$ and after treatment for 3 minutes, the total coliform reduced to nil in samples $S_{1}$ and $S_{4}$. Total coliform should be 0 in drinking water. Total coliform of two samples was zero after treatment. These two water samples are drinkable after ozonation. The correlation coefficients between different samples were not calculated because the total coliform count was very high (above 1100) before treatment in two samples.

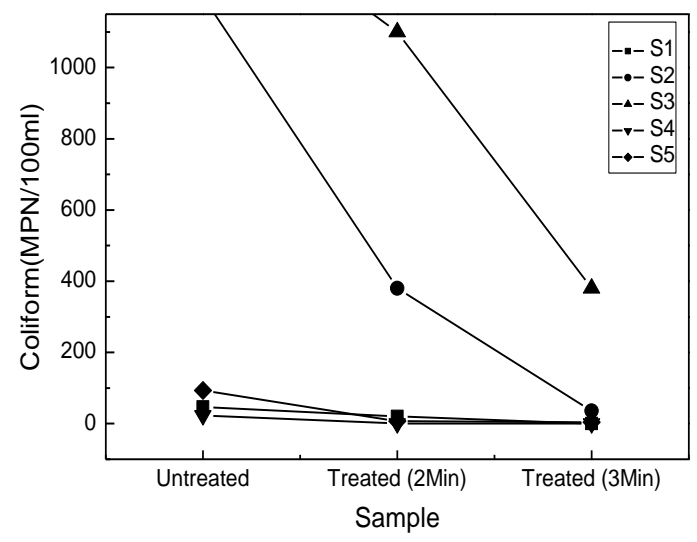

Fig. 8 Total coliform of samples 


\section{Conclusion}

Results of ozonated water samples from different sources showed slight increase in $\mathrm{pH}$ after treatment. The conductivity of water samples changed slightly after treatment by ozone. Conductivity is directly related to the amount of salts dissolved in water, and ozonation does not contribute to addition of extra ions. DO of all samples increased significantly after ozonation. BOD and COD of water samples decreased

\section{References}

[1] Armstrong A. 2009. Water Pollution Urban Waste. Nat Geosci. Vol 2: 748

[2] Bhatta R., Kayastha R., Subedi D. P., Joshi R. 2015. Treatment of Wastewater by Ozone Produced in Dielectric Barrier Discharge. Journal of Chemistry Vol 2015: Article ID 648162, 6 pages, 2015. doi:10.1155/2015/648162.

[3] Bubnov A. G., Grinevich, V. I., Kurykin, N. A. 2004. The Kinetics of Plasma-Induced Degradation of Organic Pollutants in Sewage Water. High Energy Chemistry Vol 38: 41-45.

[4] Chang M. B., Wu S. J. 1997. Experimental Study on Ozone Synthesis via Dielectric Barrier Discharges. Ozone Science Engineering Vol 19: 241-254.

[5] Droste R. Theory and Practice of Water and Wastewater Treatment. John Wiley and Sons, New York, 1996.

[6] Eliasson B., Hirth M., Kogelschatz U. 1987. Ozone Synthesis from Oxygen in Dielectric Barrier Discharges. Journal Phys. D: Applied Phys.Vol 20: 1421-1437.

[7] Glaze W. H., Kang J., Chapin D. H. 1987. The Chemistry of Water Treatment Processes Involving Ozone, Hydrogen Peroxide and Ultraviolet Radiation. Ozone Science and Engineering Vol 9: 335-352.

[8] Goel P. K. Water Pollution Causes, Effects and Control. New Age International, 2nd edition, 2006.

[9] Malik M. A., Ghaffar A., Malik S. A. 2001. Water Purification by Electrical Discharges. Plasma Sources Science and Technology Vol 10: 82-91.

[10] Mohamed E., Mohamed A., Safwat H., Nasser M., Ahmed S., Farouk E., Abdou G. 2013. Wastewater Decontamination from Microorganisms by Electro significantly after ozonation. Remarkable effect on ferrous ion concentration was observed. Iron in its ferrous state has charge of $2^{+}$. When ozone is passed through the solution containing ferrous salts, it contributes the oxygen atom that reacts with the $\mathrm{Fe}^{2+}$ to give ferric salt and hence concentration of $\mathrm{Fe}^{2+}$ decreases. There was significant reduction in the number of coliform bacteria. This showed that the ozonation process could be a useful method for reducing the microorganism present in water.

spraying Corona Discharge. Journal of Modern Physics Vol 4: 1632-1637.

[11] Montgomery M. A., Elimelech M. 2007. Water and Sanitation in Developing Contries: Including Health in the Equation. Environ. Sci. Technol. Vol 4:17-24.

[12] Omosa I. B., Wang H., Chang S., Li F. 2012. Sustainable Tertiary Wastewater Treatment is Required for Water Resources Pollution Control in Africa. Environ. Sci. technol. Vol 46: 7065-7066.

[13] Pickering A. J., Davis J. 2012. Freshwater Availability and Water Fetching Distance Affect Child Health in Sub-Saharan Africa. Environ. Sci. Technol. Vol 46: 2391-2397.

[14] Quyen N. T., Traikool T., Nitisoravut R., Onjun T. 2017. Improvement of Water Quality using Dielectric Barrier Discharge Plasma. Journal of Physics: Conference Series 860012031.

[15] Razuqi N. S., Muftin F. S, Murbat H. H., Abdalameer N. Kh. 2017. Influence of Dielectric Barrier Discharge (DBD) Cold Plasma on Water Contaminated Bacteria. Annual Research and Review in Biology Vol 14: 1-9.

[16] Subedi D. P., Tyata R. B., Khadgi A., Wong C. S. 2009. Treatment of Water by Dielectric Barrier Discharge. Journal of Science and Technology in the Tropics Vol 5: 117-123.

[17] Subedi D. P., Tyata R. B., Khadgi A., Wong C. S. 2012. Physicochemical and Microbiological Analysis of Drinking Water Treated by using Ozone. Sains Malaysiana Vol 41: 739-745.

[18] World Health Organization 2007. Revised Background Document for Development of WHO Guidelines for Drinking-water quality. 